\title{
Evaluation of the digestible lysine requirements in female turkeys from 0 to 68 days of age
}

\author{
Juliano Cesar de Paula Dorigam ${ }^{\mathrm{a}, *}$, Matias Djalma Appelt ${ }^{\mathrm{b}}$, Alex Maiorka ${ }^{\mathrm{b}}$, \\ Keysuke Muramatsu ${ }^{\mathrm{b}}$, Rafael Fernando Sens ${ }^{\mathrm{b}}$, Chayane Rocha ${ }^{\mathrm{b}}$, \\ Fabiano Dahlke ${ }^{\mathrm{c}}$ \\ a Faculdade de Ciências Agrárias e Veterinárias FCAV/UNESP, Department of Animal Science, Jaboticabal, São Paulo,4884900, Brazil \\ b Universidade Federal do Paraná UFPR, Department of Animal Science, Curitiba, Parana, 88035060, Brazil \\ c Universidade Federal de Santa Catarina UFSC, Department of Animal Science and Agrarian development, Florianópolis, Santa Catarina, \\ 88034000 , Brazil
}

\section{A R T I C L E I N F O}

\section{Article history:}

Received 3 May 2016

Received in revised form 7 August 2016

Accepted 20 August 2016

\section{Keywords:}

Amino acid

Broken line

Carcass yield

Female turkey

Quadratic polynomial

\begin{abstract}
A B S T R A C T
Over the past years, turkey meat has gained a prominent position in the global market. As lysine (Lys) is among the main essential amino acids (AA) for protein deposition in the carcass, defining Lys requirements can contribute to improving the performance and carcass yield of turkey for meat production. Thus, the objective of this study was to evaluate if the digestible Lys levels proposed by breeder's guidelines are adequate to achieve the best performance in the used rearing and feed conditions of this study. In each phase, 800 female turkeys of the BUT (British United Turkey) hybrid strain were used. The turkeys were distributed in a completely randomized design in experiment 1 (initial phase: $0-25 \mathrm{~d}$ ) and in a randomized block design in experiment 2 (growth phase: 26-48 d) and experiment 3 (finishing phase: 49-68 d). The treatments consisted of graded levels of digestible Lys with eight replications of 20 turkeys each. The digestible Lys levels tested were 13.6, 14.5, 15.8, 16.9 and $18.2 \mathrm{~g} / \mathrm{kg}$ in the initial phase; $12.2,13.2,14.4,15.4$ and $16.2 \mathrm{~g} / \mathrm{kg}$ in the growth phase; and 9.7, 10.4, 11.4, 12.1 and $13.7 \mathrm{~g} / \mathrm{kg}$ in the finishing phase. The average daily gain (ADG), average daily feed intake (ADFI), feed efficiency (FE) and carcass yield (CY) were evaluated. The ADG, FE and CY data were improved by the digestible Lys levels $(\mathrm{P}<0.05)$, and the data were adjusted to the quadratic and broken line functions. The digestible Lys level was estimated by the first intercept of the quadratic function with the plateau of the broken line function. At the end of experiment 3, the CY was evaluated (at $68 \mathrm{~d}$ ). The digestible Lys level for better ADG and FE were, respectively, $16.69 \mathrm{~g} / \mathrm{kg}$ and $16.55 \mathrm{~g} / \mathrm{kg}$ in the initial phase, $14.25 \mathrm{~g} / \mathrm{kg}$ and $14.15 \mathrm{~g} / \mathrm{kg}$ in the growth phase, and $12.23 \mathrm{~g} / \mathrm{kg}$ and $12.07 \mathrm{~g} / \mathrm{kg}$ in the finishing phase. The digestible Lys level for CY was $12.32 \mathrm{~g} / \mathrm{kg}$. The current study concludes that digestible Lys levels are in the range of the nutritional guidelines for the strain used, except in the initial phase. Due to the difference in the initial recommendation, these levels should be validated in further investigations through performance trials.
\end{abstract}

(c) 2016 Elsevier B.V. All rights reserved.

\footnotetext{
Abbreviations: Lys, lysine; AA, amino acid; d, days; ADG, average daily gain; ADFI, Average daily feed intake; CY, carcass yield; FE, feed efficiency; CW, carcass weight; BW, body weight; HPLC, high-performance liquid chromatography; ME, metabolizable energy; BUT, British United Turkey; GLM, general linear model; ANOVA, analysis of variance.

* Corresponding author.

E-mail addresses: jdorigam@gmail.com (J.C. de Paula Dorigam), matias.appelt@gmail.com (M.D. Appelt), amaiorka@ufpr.br (A. Maiorka), keysuke.muramatsu@dsm.com (K. Muramatsu),rafael.sens@brf-br.com (R.F.Sens), chay_ctba@yahoo.com.br (C.Rocha),fabiano.dahlke@ufsc.br(F.Dahlke).
} 


\section{Introduction}

The increased growth rate of turkeys has occurred through the efforts of primary breeder companies, which obtained substantial improvements in the gain rates and feed efficiencies for commercially available strains, principally in females (NRC, 1994). The processing of the carcass into convenience products such as breast meat has also expanded and come to occupy the greatest proportion of total turkey production (Case et al., 2010).

Changes in the turkey growth rate and carcass yield have been associated with the supply of amino acids (AA), such as lysine (Lys), which is a reference AA to increase animal protein deposition (TrindadeNeto et al., 2010). Both growth and carcass characteristics have changed drastically over the last 10 years, resulting in a high capacity for lean tissue deposition and a consequently greater requirement for digestible Lys (Ajinomoto, 2015). However, the latest studies on digestible Lys requirements for female turkeys are outdated (Lehmann et al., 1996; Boling and Firman, 1998; Thompson et al., 2004; Thompson et al., 2005), and the requirements are lower than those recommended by the nutritional guidelines for modern strains.

In some countries such as Brazil, female turkeys are slaughtered earlier (4-5 kg), and knowledge of the AA requirements for feed formulation is especially important in this phase; however, the requirements in the literature were determined mainly for heavier turkeys and most of them for male turkeys (Appelt, 2010). In addition, Lys is the AA reference used in the ideal protein concept for feed formulation, increasing the necessity of constantly evaluating this AA in dose-response assays (Boling and Firman, 1998). Thus, the objectives of this study was to evaluate if the digestible Lys levels proposed by breeder's guidelines are adequate to achieve the best performance in the used rearing and feed conditions of this study.

\section{Materials and methods}

\subsection{General procedures}

The experiments were conducted for female turkeys in the periods from 0 to $25,26-48$, and $49-68 \mathrm{~d}$ of age. The experiments were conducted at Carambeí-PR, Brazil, in a poultry house measuring $1200 \mathrm{~m}^{2}(100 \times 12 \mathrm{~m})$, and each experimental unit was delimited with mobile pens of $6 \mathrm{~m}^{2}(2 \times 3 \mathrm{~m})$. The treatments consisted of five diets with graded levels of digestible Lys. The limiting AA was supplemented to provide $0.85,0.93,1.00,1.08$ and 1.15 times the digestible Lys levels from the nutritional guidelines (Aviagen Turkeys, 2013), maintaining the ideal ratios between the remaining AAs. The basal diets were formulated based on corn, soybean meal, and poultry offal meal and supplemented with the industrial AAs such as DLmethionine, L-threonine, L-tryptophan, L-isoleucine, L-arginine and L-valine to meet the nutritional requirements of female turkeys (Aviagen Turkeys, 2013), except for digestible Lys, ensuring that no other AA would be limiting. The temperature inside the poultry house was controlled, with an initial temperature of $31^{\circ} \mathrm{C}$, decreasing by approximately $2{ }^{\circ} \mathrm{C}$ per week until reaching $18^{\circ} \mathrm{C}$ at $68 \mathrm{~d}$. Water and feed were supplied ad libitum throughout the experimental period. The turkeys were fed a standard diet to meet their requirements according to the strain guidelines (Aviagen Turkeys, 2013) for 0-25 and 26-48 $\mathrm{d}$ until the start of the trials in the periods from 26 to 48 and 49-68 d of age, respectively. The performance of the female turkeys during the experimental periods was evaluated by weekly weighing of the birds and the feed leftovers to calculate the average daily gain (ADG), average daily feed intake (ADFI), and feed efficiency (FE).

The Ethics Committee on Animal Use of the Federal University of Paraná, UFPR, Curitiba, approved all the procedures used this study (protocol 019/2009).

\subsection{Experiment 1}

In this experiment, 800 turkey chicks of the BUT (British United Turkey) hybrid genotype were used, with an average initial body weight $(\mathrm{BW})$ of $56.0 \pm 1.5 \mathrm{~g}$. The turkeys were distributed into a completely randomized design with five treatments and eight replications of 20 turkeys per experimental unit. The basal diets were supplemented with 0.00, 0.30, 2.10, 3.70, and $5.50 \mathrm{~g} / \mathrm{kg}$ of L-Lysine $\mathrm{HCl}(788 \mathrm{~g} / \mathrm{kg})$ with the objective of reaching levels of $13.6,14.5,15.8,16.9$, and $18.2 \mathrm{~g} / \mathrm{kg}$ of digestible Lys in the diets (Table 1). In this period, the experimental diets were provided in crumble form.

\subsection{Experiment 2}

In the second experiment, 800 female turkeys of the BUT hybrid genotype with an average initial BW of $0.949 \pm 0.108 \mathrm{~kg}$ were used. In this experiment, the female turkeys were distributed in a randomized block experimental design with five treatments and eight replications of 20 turkeys per experimental unit. The basal diets were supplemented with $0.20,1.60$, $3.30,4.70$, and $5.20 \mathrm{~g} / \mathrm{kg}$ of L-Lysine $\mathrm{HCl}(788 \mathrm{~g} / \mathrm{kg})$ with the objective of reaching levels of $12.2,13.2,14.4,15.4, \mathrm{and} 16.2 \mathrm{~g} / \mathrm{kg}$ of digestible Lys in the diets (Table 2). The experimental diets were provided in pellet form.

\subsection{Experiment 3}

In the third experiment, 800 female turkeys of the BUT hybrid genotype with an average initial BW of $1.900 \pm 0.340 \mathrm{~kg}$ were used. As in the second experiment, the female turkeys were distributed in a randomized block experimental design 
Table 1

Composition of the experimental diets (as-fed basis) in experiment 1 .

\begin{tabular}{|c|c|c|c|c|c|}
\hline \multirow[t]{2}{*}{ Ingredients, g/kg } & \multicolumn{5}{|l|}{ Diets } \\
\hline & 0.85 & 0.93 & 1.00 & 1.08 & 1.15 \\
\hline Soybean meal (460 g/kg) & 495.10 & 498.30 & 498.60 & 493.20 & 486.40 \\
\hline Corn & 373.70 & 370.60 & 367.40 & 371.60 & 376.80 \\
\hline Poultry offal meal & 45.00 & 45.00 & 45.00 & 45.00 & 45.00 \\
\hline Soybean oil & 35.00 & 35.00 & 35.00 & 34.00 & 33.00 \\
\hline Mono-dicalcium phosphate & 22.20 & 21.50 & 22.00 & 22.00 & 22.10 \\
\hline Limestone & 13.10 & 13.00 & 13.30 & 13.30 & 13.40 \\
\hline Salt & 2.00 & 2.00 & 2.00 & 2.00 & 2.00 \\
\hline Sodium bicarbonate & 1.50 & 1.50 & 1.50 & 1.50 & 1.50 \\
\hline Vitamin supplement ${ }^{\mathrm{a}}$ & 1.50 & 1.50 & 1.50 & 1.50 & 1.50 \\
\hline Mineral supplement ${ }^{\mathrm{b}}$ & 1.00 & 1.00 & 1.00 & 1.00 & 1.00 \\
\hline Choline chloride $(750 \mathrm{~g} / \mathrm{kg}$ ) & 0.60 & 0.60 & 0.60 & 0.60 & 0.60 \\
\hline L-Lysine $\mathrm{HCl}$ (788 g/kg) & 0.00 & 0.30 & 2.10 & 3.70 & 5.50 \\
\hline DL-Methionine (990 g/kg) & 4.60 & 4.60 & 4.60 & 4.60 & 4.70 \\
\hline L-Threonine (985 g/kg) & 2.10 & 2.20 & 2.30 & 2.40 & 2.50 \\
\hline L-Tryptophan (980 g/kg) & 0.30 & 0.30 & 0.30 & 0.40 & 0.40 \\
\hline L-Arginine (985 g/kg) & 0.40 & 0.60 & 0.80 & 0.90 & 1.10 \\
\hline L-Valine $(985 \mathrm{~g} / \mathrm{kg})$ & 0.90 & 0.90 & 0.90 & 1.00 & 1.14 \\
\hline L-Isoleucine (985 g/kg) & 1.00 & 1.10 & 1.20 & 1.30 & 1.40 \\
\hline \multicolumn{6}{|l|}{ Nutritional composition } \\
\hline Metabolizable energy, MJ/kg & 12.3 & 12.3 & 12.3 & 12.3 & 12.3 \\
\hline Calcium & 13.0 & 13.0 & 13.0 & 13.0 & 13.0 \\
\hline Available phosphorus & 6.5 & 6.5 & 6.5 & 6.5 & 6.5 \\
\hline Sodium & 1.6 & 1.6 & 1.6 & 1.6 & 1.6 \\
\hline Potassium & 11.2 & 11.2 & 11.2 & 11.2 & 11.2 \\
\hline Crude protein $^{c}$ & $300.0(296.5 \pm 2.475)$ & $300.0(298.1 \pm 1.344)$ & $300.0(299.2 \pm 0.566)$ & $300.0(297.7 \pm 1.626)$ & $300.0(301.1 \pm 0.778)$ \\
\hline Digestible arginine $^{c, d}$ & $19.1(19.0 \pm 0.071)$ & $19.1(19.0 \pm 0.042)$ & $19.1(19.6 \pm 0.226)$ & $19.1(19.2 \pm 0.156)$ & $19.1(19.0 \pm 0.021)$ \\
\hline Digestible lysine $e^{\mathrm{c}, \mathrm{d}}$ & $13.6(13.6 \pm 0.008)$ & $14.5(14.4 \pm 0.050)$ & $15.8(15.9 \pm 0.035)$ & $16.9(17.0 \pm 0.042)$ & $18.2(18.5 \pm 0.219)$ \\
\hline Digestible methionine $^{\mathrm{c}, \mathrm{d}}$ & $8.2(8.2 \pm 0.014)$ & $8.2(8.1 \pm 0.049)$ & $8.2(8.1 \pm 0.042)$ & $8.2(8.3 \pm 0.033)$ & $8.2(8.2 \pm 0.007)$ \\
\hline Digestible methionine + cysteine $^{\mathrm{c}, \mathrm{d}}$ & $12.0(12.0 \pm 0.007)$ & $12.0(11.9 \pm 0.085)$ & $12.0(11.9 \pm 0.057)$ & $12.0(12.0 \pm 0.021)$ & $12.0(12.1 \pm 0.028)$ \\
\hline Digestible tryptophan ${ }^{c, d}$ & $3.3(3.3 \pm 0.015)$ & $3.3(3.2 \pm 0.057)$ & $3.3(3.2 \pm 0.028)$ & $3.3(3.3 \pm 0.015)$ & $3.3(3.2 \pm 0.034)$ \\
\hline Digestible threonine $^{c, d}$ & $11.4(11.4 \pm 0.021)$ & $11.4(11.6 \pm 0.120)$ & $11.4(11.3 \pm 0.106)$ & $11.4(11.4 \pm 0.014)$ & $11.4(11.3 \pm 0.057)$ \\
\hline Digestible valine $^{c, d}$ & $12.6(12.5 \pm 0.057)$ & $12.6(12.9 \pm 0.219)$ & $12.6(12.8 \pm 0.283)$ & $12.6(12.7 \pm 0.141)$ & $12.6(12.7 \pm 0.036)$ \\
\hline Digestible isoleucine ${ }^{c, d}$ & $11.8(12.0 \pm 0.154)$ & $11.8(11.9 \pm 0.155)$ & $11.8(11.9 \pm 0.049)$ & $11.8(11.7 \pm 0.037)$ & $11.8(11.7 \pm 0.035)$ \\
\hline
\end{tabular}

a Vitamin mixture (content per kg of the diet): Vitamin A, 14000 IU; Vitamin D3, 4000 IU; Vitamin E, 70000 ppm; Vitamin K3, 5000 ppm; Vitamin B1, 4000 ppm; Vitamin B2, 15000 ppm, Vitamin B6, 6000 ppm; Vitamin B12, 30 ppm; Niacin, 70000 ppm; Pantothenic acid, 25500 ppm; Folic acid, 3000 ppm; Biotin, 40 ppm.

b Mineral mixture (content per kg of the diet): Iron, 50 ppm; Copper, 20 ppm; Iodine, 2 ppm; Zinc, 100 ppm; Manganese, 115 ppm; Selenium, 0.4 ppm.

c Values in parenthesis represent analysed crude protein and amino acids (means \pm standard deviation).

d Digestible amino acids were calculated using Rostagno et al. (2011) true digestibility coefficients.

with five treatments and eight replications of 20 turkeys per experimental unit. The basal diets were supplemented with $0.00,0.70,2.00,2.70$, and $4.80 \mathrm{~g} / \mathrm{kg}$ of L-Lysine $\mathrm{HCl}(788 \mathrm{~g} / \mathrm{kg})$ with the objective of reaching levels of 9.7, 10.4, 11.4, 12.1, and $13.7 \mathrm{~g} / \mathrm{kg}$ of digestible Lys in the diets (Table 3). In this period, the experimental diet was also provided in pellet form.

At $68 \mathrm{~d}$ of age, the birds were weighed to obtain BW, and the turkeys subsequently went through a fasting period of eight hours. The fasted turkeys were weighed, and five turkeys per replication were slaughtered to determine carcass yield (CY), which was calculated by dividing the grams of carcass weight without feet, head and neck (CW) by the kilograms of BW.

\subsection{Chemical analysis}

The total nitrogen content of the experimental diets was analyzed in a nitrogen distiller (kjeltec TM 8400; Foss ${ }^{\circledR}$ ) using the Kjeldahl method (Method No 2001.11) according to AOAC (2005). A factor of 6.25 was used in the conversion of the nitrogen value to crude protein (CP). The total AA other than tryptophan in the diets were determined after hydrolysis of the protein under acidic conditions. The samples were hydrolysed for $23 \mathrm{~h}$ at $110^{\circ} \mathrm{C}$ after performic acid oxidation of the methionine (transformed into methionine sulfone) and the cysteine (transformed into cysteic acid). The determination of total tryptophan in the experimental feeds was performed after basic hydrolysis of the protein. The samples were hydrolysed under alkaline conditions with barium hydroxide and heated in autoclave at $120^{\circ} \mathrm{C}$ for $16 \mathrm{~h}$. The hydrolysates were acidified with chlorhydric acid to $\mathrm{pH} 3.0$ and them separated by reverse phase high performance liquid chromatography (HPLC) and determined by fluorometric detection. These values were corrected for digestible AA using the tabulated coefficients of digestibility (Rostagno et al., 2011). This information was used to check de precision of feed formulation and the expected and analyzed values (mean \pm standard deviation) are presented in Tables 1-3. 
Table 2

Composition of the experimental diets (as-fed basis) in experiment 2.

\begin{tabular}{|c|c|c|c|c|c|}
\hline \multirow[t]{2}{*}{ Ingredients, g/kg } & \multicolumn{5}{|l|}{ Diets } \\
\hline & 0.85 & 0.93 & 1.00 & 1.08 & 1.15 \\
\hline Soybean meal (460 g/kg) & 393.00 & 393.00 & 388.00 & 383.00 & 395.00 \\
\hline Corn & 471.84 & 471.33 & 475.97 & 479.95 & 464.14 \\
\hline Poultry offal meal & 53.00 & 51.00 & 50.00 & 50.00 & 54.00 \\
\hline Soybean oil & 35.00 & 35.00 & 34.00 & 33.00 & 35.00 \\
\hline Mono-dicalcium phosphate & 16.60 & 17.00 & 17.10 & 17.10 & 16.50 \\
\hline Limestone & 12.80 & 13.10 & 13.10 & 13.20 & 12.70 \\
\hline Salt & 2.00 & 2.00 & 2.00 & 2.00 & 2.00 \\
\hline Sodium bicarbonate & 1.50 & 1.50 & 1.50 & 1.50 & 1.50 \\
\hline Vitamin supplement $^{\mathrm{a}}$ & 1.50 & 1.50 & 1.50 & 1.50 & 1.50 \\
\hline Mineral supplement ${ }^{\mathrm{b}}$ & 1.00 & 1.00 & 1.00 & 1.00 & 1.00 \\
\hline Choline chloride $(750 \mathrm{~g} / \mathrm{kg}$ ) & 0.56 & 0.56 & 0.56 & 0.56 & 0.56 \\
\hline L-Lysine $\mathrm{HCl}(788 \mathrm{~g} / \mathrm{kg})$ & 0.00 & 1.60 & 3.30 & 4.70 & 5.20 \\
\hline DL-Methionine (990 g/kg) & 4.10 & 4.10 & 4.20 & 4.20 & 4.10 \\
\hline L-Threonine $(985 \mathrm{~g} / \mathrm{kg})$ & 2.40 & 2.40 & 2.50 & 2.60 & 2.30 \\
\hline L-Tryptophan (980 g/kg) & 0.40 & 0.40 & 0.40 & 0.50 & 0.40 \\
\hline L-Arginine (985 g/kg) & 1.28 & 1.38 & 1.55 & 1.70 & 1.23 \\
\hline L-Valine $(985 \mathrm{~g} / \mathrm{kg})$ & 1.55 & 1.60 & 1.70 & 1.79 & 1.35 \\
\hline L-Isoleucine (985 g/kg) & 1.47 & 1.53 & 1.62 & 1.71 & 1.35 \\
\hline \multicolumn{6}{|l|}{ Nutritional composition } \\
\hline Metabolizable energy, MJ/kg & 12.7 & 12.7 & 12.7 & 12.7 & 12.7 \\
\hline Calcium & 12.0 & 12.0 & 12.0 & 12.0 & 12.0 \\
\hline Available phosphorus & 5.5 & 5.5 & 5.5 & 5.5 & 5.5 \\
\hline Sodium & 1.6 & 1.6 & 1.6 & 1.6 & 1.6 \\
\hline Potassium & 9.4 & 9.4 & 9.4 & 9.4 & 9.4 \\
\hline Crude protein $^{c}$ & $265.0(263.0 \pm 1.414)$ & $265.0(265.5 \pm 0.354)$ & $265.0(264.7 \pm 0.212)$ & $265.0(264.2 \pm 0.566)$ & $265(269.9 \pm 3.465)$ \\
\hline Digestible arginine $e^{c, d}$ & $17.0(17.2 \pm 0.297)$ & $17.0(17.1 \pm 0.191)$ & $17.0(17.0 \pm 0.028)$ & $17.0(16.9 \pm 0.134)$ & $17.0(17.2 \pm 0.311)$ \\
\hline Digestible lysine $^{\mathrm{c}, \mathrm{d}}$ & $12.2(12.3 \pm 0.085)$ & $13.2(13.2 \pm 0.029)$ & $14.4(14.5 \pm 0.064)$ & $15.4(15.6 \pm 0.113)$ & $16.2(16.5 \pm 0.212)$ \\
\hline Digestible methionine ${ }^{\mathrm{c}, \mathrm{d}}$ & $7.4(7.4 \pm 0.007)$ & $7.4(7.4 \pm 0.014)$ & $7.4(7.3 \pm 0.021)$ & $7.4(7.30 \pm 0.021)$ & $7.4(7.5 \pm 0.028)$ \\
\hline Digestible methionine + cysteine $e^{c, d}$ & $10.7(10.6 \pm 0.021)$ & $10.7(10.6 \pm 0.035)$ & $10.7(10.7 \pm 0.014)$ & $10.7(10.8 \pm 0.071)$ & $10.7(10.8 \pm 0.028)$ \\
\hline Digestible tryptophan ${ }^{c, d}$ & $2.9(3.0 \pm 0.035)$ & $2.9(3.0 \pm 0.028)$ & $2.9(2.9 \pm 0.021)$ & $2.9(2.9 \pm 0.014)$ & $2.9(2.8 \pm 0.071)$ \\
\hline Digestible threonine ${ }^{c, d}$ & $10.2(10.3 \pm 0.099)$ & $10.2(10.2 \pm 0.071)$ & $10.2(10.3 \pm 0.057)$ & $10.2(10.0 \pm 0.141)$ & $10.2(10.5 \pm 0.141)$ \\
\hline Digestible valine $^{\mathrm{c}, \mathrm{d}}$ & $11.6(11.5 \pm 0.049)$ & $11.6(11.8 \pm 0.106)$ & $11.6(11.4 \pm 0.205)$ & $11.6(11.8 \pm 0.269)$ & $11.6(11.7 \pm 0.057)$ \\
\hline Digestible isoleucine $\mathrm{e}^{\mathrm{c}, \mathrm{d}}$ & $10.5(10.3 \pm 0.148)$ & $10.5(10.7 \pm 0.424)$ & $10.5(10.4 \pm 0.078)$ & $10.5(10.5 \pm 0.014)$ & $10.5(10.6 \pm 0.099)$ \\
\hline
\end{tabular}

a Vitamin mixture (content per kg of the diet): Vitamin A, 11200 IU; Vitamin D3, 3200 IU; Vitamin E, 56000 ppm; Vitamin K3, 4000 ppm; Vitamin B1, 3200 ppm; Vitamin B2, 12000 ppm, Vitamin B6, 4800 ppm; Vitamin B12, 24 ppm; Niacin, 56000 ppm; Pantothenic acid, 18000 ppm; Folic acid, 2400 ppm; Biotin, 32 ppm.

b Mineral mixture (content per kg of the diet): Iron, 50 ppm; Copper, 20 ppm; Iodine, 2 ppm; Zinc, 100 ppm; Manganese, 115 ppm; Selenium, 0.4 ppm.

c Values in parenthesis represent analysed crude protein and amino acids (means \pm standard deviation).

d Digestible amino acids were calculated using Rostagno et al. (2011) true digestibility coefficients.

\subsection{Statistical methods}

The performance data for ADG, ADFI, FE, BW, CW and CY were subjected to an ANOVA procedure for the corresponding experimental designs used in the assays using the general linear model (GLM) procedure in the SAS ${ }^{\circledR}$ software (SAS Inst. Inc., Cary, NC). Linear and quadratic responses for graded levels of digestible Lys were assessed using orthogonal polynomial contrast statements and the statistical significance were based on $\mathrm{P} \leq 0.05$. The responses of ADG, FE and CY to digestible Lys levels were adjusted by the broken line approach (Robbins et al., 1979) according to the equation $Y=a_{1}+a_{2} *\left(a_{3}-\right.$ Lys), where $Y$ is the response variable obtained with the digestible Lys levels, Lys is the digestible Lys level in $g / \mathrm{kg}$, $\mathrm{a}_{1}$ is the estimated value at the response plateau, $a_{2}$ is the slope of the function, and $a_{3}$ is the digestible Lys level estimated at the break point, considered the optimal level of digestible Lys. These performance data were also fitted to a quadratic response curve (Draper and Smith, 1981) according to the equation $Y=b_{1}+b_{2} *$ Lys $+b_{3}{ }^{*}$ Lys $^{2}$, where Lys is the digestible Lys level in $\mathrm{g} / \mathrm{kg}, \mathrm{b}_{1}$ is the intercept of the model, $b_{2}$ is the linear coefficient, and $b_{3}$ is the quadratic coefficient. The relation $-b_{2} /(2$ ${ }^{*} b_{3}$ ) gives the digestible Lys level estimated at the maximum point in the quadratic function. The digestible Lys levels were estimated from the quadratic models by establishing the first point at which the quadratic response curve intersected the plateau value established from the one-slope fitted broken line, as described by Baker et al. (2002). According to these authors, the optimal digestible Lys level (intercept value) can be calculated using the quadratic regression equation once the plateau of the response in the broken line function is determined. The maximum response at the plateau from the broken line equation can be substituted into the polynomial quadratic equation to obtain the equation $a_{1}=b_{1}+b_{2} * L^{2} s+b_{3} *$ Lys ${ }^{2}$ and then the first intercept where the quadratic curve intersects the plateau of the broken line can be determined. 
Table 3

Composition of the experimental diets (as-fed basis) in experiment 3.

\begin{tabular}{|c|c|c|c|c|c|}
\hline \multirow[t]{2}{*}{ Ingredients, $\mathrm{g} / \mathrm{kg}$} & \multicolumn{5}{|l|}{ Diets } \\
\hline & 0.85 & 0.93 & 1.00 & 1.08 & 1.15 \\
\hline Soybean meal (460 g/kg) & 264.00 & 273.00 & 273.00 & 276.00 & 275.00 \\
\hline Corn & 547.07 & 541.37 & 541.39 & 531.47 & 533.89 \\
\hline Poultry offal meal & 60.00 & 55.00 & 55.00 & 60.00 & 56.00 \\
\hline Soybean oil & 33.00 & 35.00 & 35.00 & 35.00 & 35.00 \\
\hline Mono-dicalcium phosphate & 12.40 & 12.50 & 12.80 & 12.30 & 12.30 \\
\hline Limestone & 9.20 & 9.30 & 9.50 & 9.20 & 9.20 \\
\hline Salt & 2.00 & 2.00 & 2.00 & 2.00 & 2.00 \\
\hline Sodium bicarbonate & 1.50 & 1.50 & 1.50 & 1.50 & 1.50 \\
\hline Vitamin supplement ${ }^{\mathrm{a}}$ & 1.50 & 1.50 & 1.50 & 1.50 & 1.50 \\
\hline Mineral supplement ${ }^{\mathrm{b}}$ & 1.00 & 1.00 & 1.00 & 1.00 & 1.00 \\
\hline Choline chloride $(750 \mathrm{~g} / \mathrm{kg})$ & 0.56 & 0.56 & 0.56 & 0.56 & 0.56 \\
\hline L-Lysine $\mathrm{HCl}(788 \mathrm{~g} / \mathrm{kg})$ & 0.00 & 0.70 & 2.00 & 2.70 & 4.80 \\
\hline DL-Methionine $(990 \mathrm{~g} / \mathrm{kg})$ & 2.90 & 2.90 & 2.90 & 2.80 & 2.90 \\
\hline L-Threonine (985 g/kg) & 1.70 & 1.70 & 1.70 & 1.70 & 1.70 \\
\hline L-Tryptophan (980 g/kg) & 0.40 & 0.40 & 0.40 & 0.40 & 0.40 \\
\hline L-Arginine (985 g/kg) & 1.47 & 1.33 & 1.42 & 1.15 & 1.24 \\
\hline L-Valine (985 g/kg) & 0.60 & 0.58 & 0.63 & 0.41 & 0.52 \\
\hline L-Isoleucine (985 g/kg) & 0.70 & 0.67 & 0.71 & 0.51 & 0.60 \\
\hline \multicolumn{6}{|l|}{ Nutritional composition } \\
\hline Metabolizable energy, MJ/kg & 13.4 & 13.4 & 13.4 & 13.4 & 13.4 \\
\hline Calcium & 10.0 & 10.0 & 10.0 & 10.0 & 10.0 \\
\hline Available phosphorus & 4.7 & 4.7 & 4.7 & 4.7 & 4.7 \\
\hline Sodium & 1.7 & 1.7 & 1.7 & 1.7 & 1.7 \\
\hline Potassium & 7.3 & 7.3 & 7.3 & 7.3 & 7.3 \\
\hline Crude protein ${ }^{c}$ & $250.0(244.0 \pm 4.243)$ & $250.0(245.1 \pm 3.465)$ & $250.0(245.2 \pm 3.394)$ & $250.0(248.5 \pm 1.061)$ & $250.0(249.7 \pm 0.212)$ \\
\hline Digestible arginine $^{\mathrm{c}, \mathrm{d}}$ & $14.7(14.5 \pm 0.184)$ & $14.7(14.8 \pm 0.092)$ & $14.7(14.4 \pm 0.148)$ & $14.7(15.0 \pm 0.276)$ & $14.7(14.8 \pm 0.255)$ \\
\hline Digestible lysine $^{\mathrm{c}, \mathrm{d}}$ & $9.7(9.5 \pm 0.064)$ & $10.4(10.3 \pm 0.042)$ & $11.4(11.3 \pm 0.035)$ & $12.1(12.0 \pm 0.064)$ & $13.7(13.8 \pm 0.049)$ \\
\hline Digestible methionine ${ }^{\mathrm{c}, \mathrm{d}}$ & $6.3(6.2 \pm 0.024)$ & $6.3(6.3 \pm 0.021)$ & $6.3(6.3 \pm 0.014)$ & $6.3(6.3 \pm 0.013)$ & $6.3(6.3 \pm 0.008)$ \\
\hline Digestible methionine + cysteine $\mathrm{c}^{\mathrm{c}, \mathrm{d}}$ & $9.6(9.5 \pm 0.035)$ & $9.6(9.8 \pm 0.141)$ & $9.6(9.6 \pm 0.009)$ & $9.6(9.4 \pm 0.212)$ & $9.6(9.5 \pm 0.028)$ \\
\hline Digestible tryptophan ${ }^{\mathrm{c}, \mathrm{d}}$ & $2.4(2.3 \pm 0.021)$ & $2.4(2.4 \pm 0.007)$ & $2.4(2.5 \pm 0.035)$ & $2.4(2.4 \pm 0.014)$ & $2.4(2.3 \pm 0.021)$ \\
\hline Digestible threonine $^{\mathrm{c}, \mathrm{d}}$ & $8.9(8.8 \pm 0.022)$ & $8.9(8.9 \pm 0.010)$ & $8.9(9.0 \pm 0.064)$ & $8.9(8.8 \pm 0.049)$ & $8.9(9.1 \pm 0.127)$ \\
\hline Digestible valine $e^{\mathrm{c}, \mathrm{d}}$ & $9.9(9.9 \pm 0.007)$ & $9.9(10.1 \pm 0.219)$ & $9.9(10.0 \pm 0.113)$ & $9.9(9.7 \pm 0.163)$ & $9.9(10.0 \pm 0.057)$ \\
\hline Digestible isoleucine $e^{\mathrm{c}, \mathrm{d}}$ & $8.9(8.9 \pm 0.023)$ & $8.9(9.0 \pm 0.078)$ & $8.9(9.1 \pm 0.178)$ & $8.9(9.0 \pm 0.177)$ & $8.9(8.8 \pm 0.156)$ \\
\hline
\end{tabular}

a Vitamin mixture (content per kg of the diet): Vitamin A, 7840 IU; Vitamin D3, 2240 IU; Vitamin E, 39200 ppm; Vitamin K3, 2800 ppm; Vitamin B1, 2240 ppm; Vitamin B2, 8400 ppm, Vitamin B6, 3360 ppm; Vitamin B12, 17 ppm; Niacin, 39200 ppm; Pantothenic acid, 12600 ppm; Folic acid, 1680 ppm; Biotin, $224 \mathrm{ppm}$.

b Mineral mixture (content per kg of the diet): Iron, 50 ppm; Copper, 20 ppm; Iodine, 2 ppm; Zinc, 100 ppm; Manganese, 115 ppm; Selenium, 0.4 ppm.

c Values in parenthesis represent analysed crude protein and amino acids (means \pm standard deviation).

d Digestible amino acids were calculated using Rostagno et al. (2011) true digestibility coefficients.

\section{Results}

\subsection{Evaluation of the performance parameters}

The ADG and FE responses were affected $(\mathrm{P}<0.05)$ by the graded levels of digestible Lys (Table 4 ) in the three experiments. However, the ADFI was not affected by the graded levels of digestible Lys in the third experiment $(P>0.05)$. The ADG was improved as the digestible Lys level increased, mainly from the first to the second dietary level. However, the ADFI was improved as the digestible Lys levels increased in the first experiment, but in the second experiment, the ADFI was reduced after the first dietary level. The FE responded quadratically as the digestible Lys levels increased $(\mathrm{P}<0.05)$.

In the third experiment, the $C Y$ was affected $(P<0.05)$ by the graded levels of digestible Lys (Table 5$)$. The CW was improved with the graded levels of digestible Lys as well as the BW response $(\mathrm{P}<0.05)$. The CY responded quadratically as the digestible Lys levels increased $(\mathrm{P}<0.05)$.

\subsection{Experiment 1}

The broken line analysis predicted a break point in the ADG and FE at $16.02 \mathrm{~g} / \mathrm{kg}$ and $15.98 \mathrm{~g} / \mathrm{kg}$ of digestible Lys, respectively. The performance data fit very well to the broken line function for ADG $\left(R^{2}=0.96\right)$ and $F E\left(R^{2}=0.99\right)$, as shown in Fig. 1. The polynomial quadratic function also showed a good fit for ADG $\left(R^{2}=0.97\right)$ and $F E\left(R^{2}=0.97\right)$. The digestible Lys level estimated at the maximum point in the polynomial quadratic function was $17.47 \mathrm{~g} / \mathrm{kg}$ for ADG and $17.34 \mathrm{~g} / \mathrm{kg}$ for FE. The optimal digestible Lys level calculated at the first intercept of the broken line (on the plateau) and the quadratic fitted line for ADG and FE occurred at 16.69 and $16.55 \mathrm{~g} / \mathrm{kg}$ of digestible Lys, respectively. 
Table 4

Effects of the graded levels of digestible lysine on average daily gain (ADG), average daily feed intake (ADFI) and feed efficiency (FE) of female turkeys within different age periods.

\begin{tabular}{|c|c|c|c|}
\hline Digestible lysine levels, $\mathrm{g} / \mathrm{kg}$ & $\mathrm{ADG}, \mathrm{g} / \mathrm{d}$ & ADFI, g/d & $\mathrm{FE}, \mathrm{g} / \mathrm{kg}$ \\
\hline \multicolumn{4}{|l|}{ Experiment 1 (from 0 to $25 \mathrm{~d}$ ) } \\
\hline 13.60 & 31.71 & 41.50 & 740.00 \\
\hline 14.50 & 33.08 & 44.25 & 747.57 \\
\hline 15.80 & 35.13 & 45.92 & 765.03 \\
\hline 16.90 & 35.08 & 45.75 & 766.78 \\
\hline 18.20 & 35.75 & 46.67 & 766.02 \\
\hline SEM & 1.78 & 1.92 & 0.01 \\
\hline \multicolumn{4}{|l|}{ Probability $^{\mathrm{a}}$} \\
\hline Linear & $<0.0001$ & $<0.0001$ & 0.0013 \\
\hline Quadratic & $<0.0001$ & $<0.0001$ & 0.0012 \\
\hline \multicolumn{4}{|l|}{ Experiment 2 (from 26 to $48 \mathrm{~d}$ ) } \\
\hline 12.20 & 53.05 & 105.12 & 504.66 \\
\hline 13.20 & 56.11 & 101.31 & 553.84 \\
\hline 14.40 & 59.00 & 100.32 & 588.12 \\
\hline 15.40 & 58.05 & 100.50 & 577.61 \\
\hline 16.20 & 58.22 & 101.25 & 575.01 \\
\hline SEM & 1.91 & 2.34 & 0.03 \\
\hline \multicolumn{4}{|l|}{ Probability $^{\mathrm{a}}$} \\
\hline Linear & $<0.0001$ & 0.0112 & $<0.0001$ \\
\hline Quadratic & 0.0026 & 0.0041 & 0.0002 \\
\hline \multicolumn{4}{|l|}{ Experiment 3 (from 49 to $68 \mathrm{~d}$ ) } \\
\hline 9.70 & 122.51 & 228.43 & 536.31 \\
\hline 10.40 & 123.96 & 222.69 & 556.63 \\
\hline 11.40 & 128.47 & 226.07 & 568.29 \\
\hline 12.10 & 129.20 & 223.11 & 579.07 \\
\hline 13.70 & 129.48 & 224.96 & 575.57 \\
\hline SEM & 3.28 & 3.35 & 0.02 \\
\hline \multicolumn{4}{|l|}{ Probability $^{\mathrm{a}}$} \\
\hline Linear & $<0.0001$ & 0.0753 & $<0.0001$ \\
\hline Quadratic & 0.0049 & 0.0510 & 0.0003 \\
\hline
\end{tabular}

a Linear and quadratic responses for graded levels of digestible lysine were assessed using orthogonal polynomial contrast statements and the statistical significance were based on $\mathrm{P} \leq 0.05$

Table 5

Effects of the graded levels of digestible lysine on body weight (BW), carcass weight (CW) and carcass yield (CY) of 68-day-old female turkeys.

\begin{tabular}{|c|c|c|c|}
\hline Digestible Lysine levels, g/kg & $\mathrm{BW}, \mathrm{kg}$ & CW, g & $\mathrm{CY}, \mathrm{g} / \mathrm{kg}$ \\
\hline 9.70 & 4.281 & 2840 & 665 \\
\hline 10.40 & 4.301 & 2900 & 673 \\
\hline 11.40 & 4.335 & 3007 & 685 \\
\hline 12.10 & 4.409 & 2982 & 684 \\
\hline 13.70 & 4.400 & 3018 & 691 \\
\hline SEM & 70 & 56 & 10 \\
\hline \multicolumn{4}{|l|}{ Probability $^{\mathrm{a}}$} \\
\hline Linear & $<0.0001$ & $<0.0001$ & 0.0001 \\
\hline Quadratic & $<0.0001$ & 0.0002 & 0.0446 \\
\hline
\end{tabular}

a Linear and quadratic responses for graded levels of digestible lysine were assessed using orthogonal polynomial contrast statements and the statistical significance were based on $\mathrm{P} \leq 0.05$.

\subsection{Experiment 2}

The broken line analysis (single-slope model) predicted a break point in the ADG and FE at $13.98 \mathrm{~g} / \mathrm{kg}$ and $13.73 \mathrm{~g} / \mathrm{kg}$ of digestible Lys, respectively. The performance data in this experiment also fit very well to the broken line function for ADG $\left(R^{2}=0.97\right)$ and FE $\left(R^{2}=0.99\right)$, as shown in Fig. 2. The polynomial quadratic function also showed a good fit for ADG $\left(R^{2}=0.96\right)$ and $F E\left(R^{2}=0.98\right)$. The digestible Lys level estimated at the maximum point in the polynomial quadratic function was $15.06 \mathrm{~g} / \mathrm{kg}$ for ADG and $14.97 \mathrm{~g} / \mathrm{kg}$ for FE. The optimal digestible Lys level calculated at the first intercept of the broken line (on the plateau) and the quadratic fitted line for ADG and FE occurred at $14.25 \mathrm{~g} / \mathrm{kg}$ and $14.15 \mathrm{~g} / \mathrm{kg}$ of digestible Lys, respectively.

\subsection{Experiment 3}

The broken line analysis predicted a break point in the ADG, FE, and CY at 11.91, 11.79, and $11.58 \mathrm{~g} / \mathrm{kg}$ of digestible Lys, respectively. The performance data fit very well to the broken line function for $A D G\left(R^{2}=0.97\right), F E\left(R^{2}=0.96\right)$, and CY 


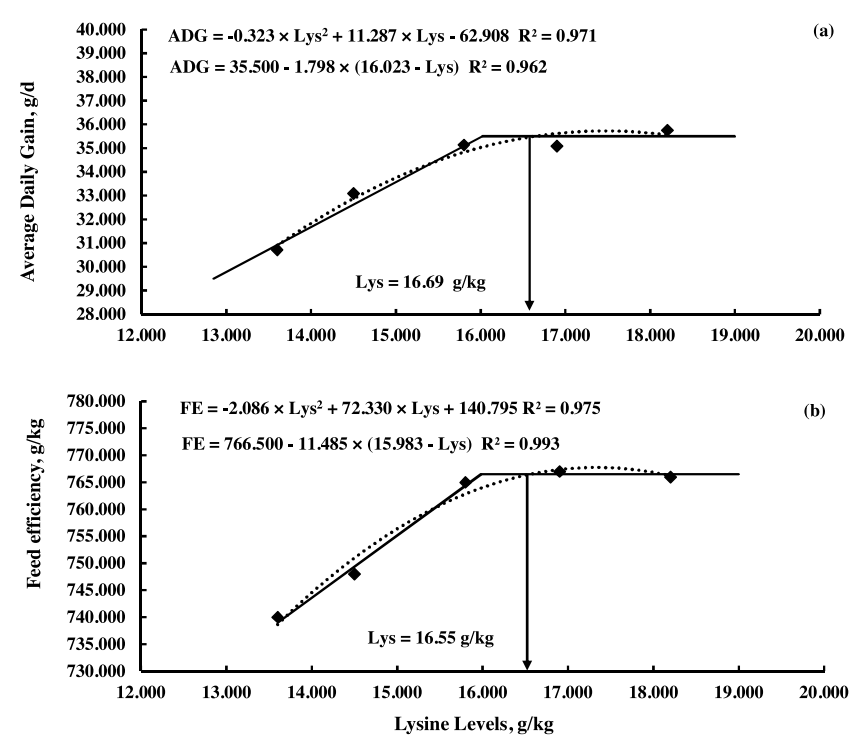

Fig. 1. Fit of the quadratic polynomial and broken line functions for (a) average daily gain (ADG) and (b) feed efficiency (FE) responses of 0-25-day-old turkey hens receiving graded levels of digestible lysine.

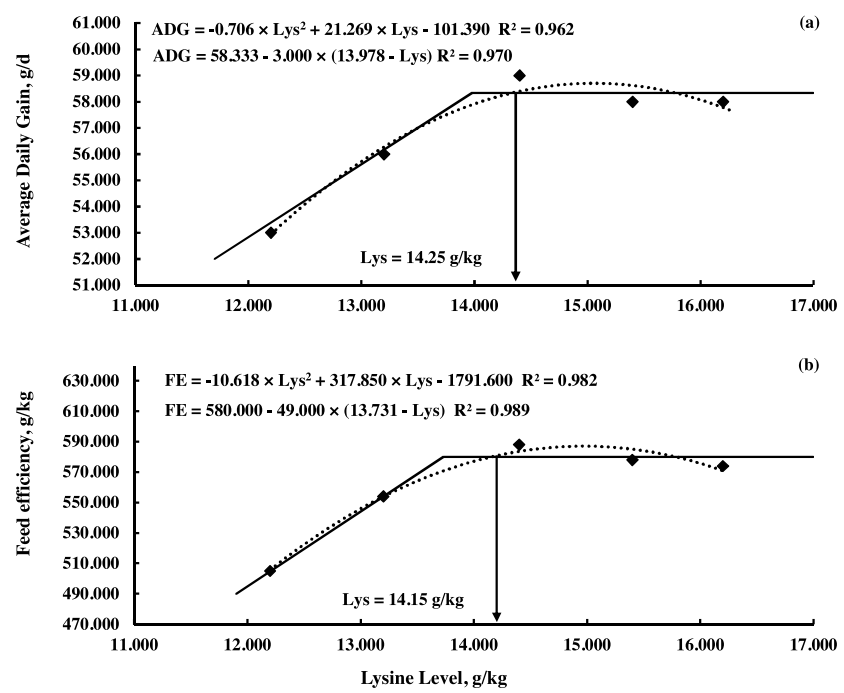

Fig. 2. Fit of the quadratic polynomial and broken line functions for (a) average daily gain (ADG) and (b) feed efficiency (FE) responses of 26-48-day-old turkey hens receiving graded levels of digestible lysine.

$\left(R^{2}=0.83\right)$, as shown in Fig. 3. The polynomial quadratic function also showed a good fit for $A D G\left(R^{2}=0.97\right), F E\left(R^{2}=0.98\right)$, and $\mathrm{CY}\left(\mathrm{R}^{2}=0.97\right)$. The digestible Lys level estimated at the maximum point in the polynomial quadratic function was $13.07 \mathrm{~g} / \mathrm{kg}$ for ADG, $12.77 \mathrm{~g} / \mathrm{kg}$ for FE and $13.51 \mathrm{~g} / \mathrm{kg}$ for CY. The optimal digestible Lys level calculated at the first intercept of the broken line (on the plateau) and the quadratic fitted line for ADG, FE and CY occurred at $12.23,12.07$, and $12.32 \mathrm{~g} / \mathrm{kg}$ of digestible Lys, respectively.

\section{Discussion}

The purpose of this study was to evaluate if the digestible Lys levels proposed by breeders guidelines are adequate to achieve the best performance in the used rearing and feed conditions of this study. This study adopted the approach proposed by the researchers from Illinois (Baker et al., 2002) to estimate the requirements of digestible Lys for female turkeys, which provided good results. In this approach, the objective prediction uses the plateau value from the one slope broken line analysis and the polynomial quadratic fit, and the requirements are estimated using the intercept of the quadratic curve and the plateau response curve. As stated by Pesti et al. (2009), there are advantages and disadvantages to use the broken line 

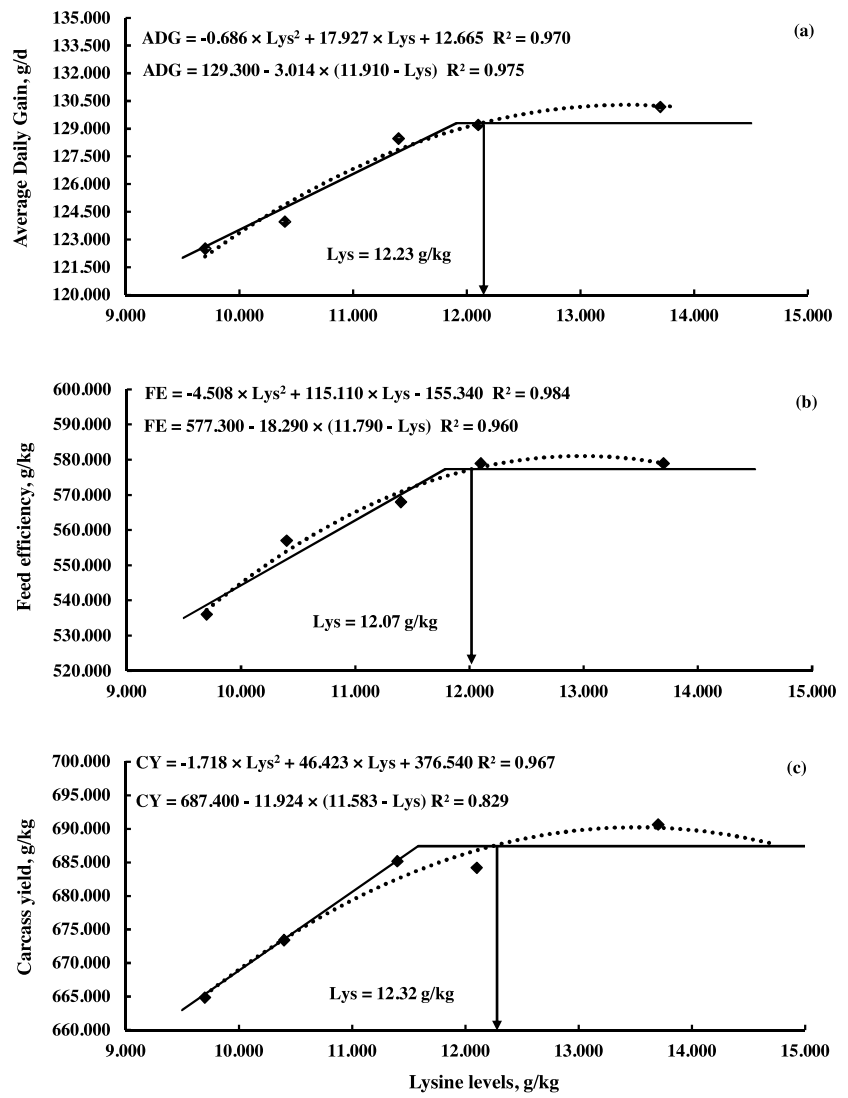

Fig. 3. Fit of the quadratic polynomial and broken line functions for (a) average daily gain (ADG) and (b) feed efficiency (FE) responses of 49-68-day-old female turkey receiving graded levels of digestible lysine; and (c) carcass yield (CY) of female turkeys at 68 days.

Table 6

Literature survey of the optimal digestible lysine levels recommended for female turkeys depending on the response criteria used.

\begin{tabular}{|c|c|c|c|}
\hline Sources & Age period (days) & Requirement (g/kg) & Response criteria \\
\hline \multirow[t]{3}{*}{ Thompson et al. (2004) } & $4-15$ & 12.9 & Average daily gain \\
\hline & $29-40$ & 11.6 & Average daily gain \\
\hline & $29-40$ & 11.2 & Feed efficiency \\
\hline \multirow[t]{2}{*}{ Thompson et al. (2005) } & $46-57$ & 10.4 & Average daily gain \\
\hline & $46-57$ & 10.7 & Feed efficiency \\
\hline \multirow[t]{2}{*}{ Boling and Firman (1998) } & $8-21$ & 13.2 & Average daily gain \\
\hline & $8-21$ & 13.4 & Feed efficiency \\
\hline \multirow[t]{3}{*}{ BUT guidelines (Aviagen Turkeys, 2013) } & $0-25$ & 17.3 & Average daily gain \\
\hline & $26-48$ & 14.1 & Average daily gain \\
\hline & $49-68$ & 12.0 & Average daily gain \\
\hline \multirow[t]{2}{*}{ NRC $(1994)^{\mathrm{a}}$} & $0-28$ & 13.6 & Average daily gain \\
\hline & $28-56$ & 12.8 & Average daily gain \\
\hline \multirow{7}{*}{ Current study } & $0-25$ & 16.7 & Average daily gain \\
\hline & $0-25$ & 16.6 & Feed efficiency \\
\hline & $26-48$ & 14.3 & Average daily gain \\
\hline & $26-48$ & 14.2 & Feed efficiency \\
\hline & $49-68$ & 12.2 & Average daily gain \\
\hline & $49-68$ & 12.1 & Feed efficiency \\
\hline & $49-68$ & 12.3 & Carcass yield \\
\hline
\end{tabular}

\footnotetext{
a Considering lysine digestibility of 0.85 in corn and soybean meal in order to obtain digestible values for comparison (Firman, 1992).
}

and polynomial quadratic functions, but the association between them makes it possible to overcome the disadvantages of these two functions to obtain a more reliable estimate of the AA requirements for turkeys.

The differences in digestible lysine recommendations found in literature have been attributed to the response criteria. A summary of the recommended digestible lysine levels from the literature for female turkeys in different ages and different response criteria are presented in Table 6. 
Considering the same metabolizable energy (ME) concentration in the feed as in the present study, the commercial nutritional recommendations for female turkeys (Aviagen Turkeys, 2013) would be $17.30 \mathrm{~g} / \mathrm{kg}(12.29 \mathrm{MJ} / \mathrm{kg}$ ), $14.10 \mathrm{~g} / \mathrm{kg}$ $(12.75 \mathrm{MJ} / \mathrm{kg})$ and $12.00 \mathrm{~g} / \mathrm{kg}(13.38 \mathrm{MJ} / \mathrm{kg})$ of digestible Lys in the periods from 0 to $25,26-48$, and $49-68 \mathrm{~d}$, respectively (Table 6). The requirements estimated in this study based on the FE response were similar to these recommendations in the periods from 26 to $48 \mathrm{~d}(14.15 \mathrm{~g} / \mathrm{kg}$ of digestible Lys) and from 49 to $68 \mathrm{~d}(12.07 \mathrm{~g} / \mathrm{kg}$ of digestible Lys), but not in the period from 0 to 25 days $(16.55 \mathrm{~g} / \mathrm{kg}$ of digestible Lys). This difference in the recommendation from 0 to $25 \mathrm{~d}$ can be attributed to the metabolizable energy and digestible amino acids provided by the breederís guidelines which are based on adult chicken values due to the lack in information available to assign specific turkey values (Aviagen Turkeys, 2013).

The digestible Lys requirements of female turkeys during the initial period (0-6 wk) were estimated to be $13.20 \mathrm{~g} / \mathrm{kg}$ for optimum growth and $13.40 \mathrm{~g} / \mathrm{kg}$ for optimum feed conversion by broken line analysis in the study of Boling and Firman (1998). In fact, the breakpoints of the fitted broken line predict minimal requirement values, contributing to the great difference from the recommendations in this study; therefore, these differences would be minimized if the plateau value from the broken line and the quadratic fits is used in the estimates, according to the assumptions made by Baker et al. (2002). The most recent study with female turkeys showed that digestible Lys requirements are $12.90 \mathrm{~g} / \mathrm{kg}$ for ADG from 4 to 15 d; $11.60 \mathrm{~g} / \mathrm{kg}$ for ADG and $11.20 \mathrm{~g} / \mathrm{kg}$ for feed conversion from 29 to $40 \mathrm{~d}$ (Thompson et al., 2004); $10.40 \mathrm{~g} / \mathrm{kg}$ for ADG and $10.70 \mathrm{~g} / \mathrm{kg}$ for feed conversion from 46 to 57 days (Thompson et al., 2005). These values are far lower than the results obtained in the current study and even lower than the recommendations of the nutritional guidelines (Table 6). These differences in the digestible Lys requirements are probably due to the genetic progress of the turkey performance, when the available literature is relatively old (Lemme et al., 2002), or because of the difference in potential from those birds used in comparison to this study.

Another aspect is the range of the digestible Lys levels and the dietary crude protein (CP) level in the experimental diets used by those researchers, which were lower than the levels studied in the current study from 0 to $25 \mathrm{~d}$. Thompson et al. (2004) formulated a basal diet with $206 \mathrm{~g} / \mathrm{kg}$ CP and digestible Lys levels from 10.8 to $14.3 \mathrm{~g} / \mathrm{kg}$, while Boling and Firman (1998) formulated a basal diet with $216 \mathrm{~g} / \mathrm{kg}$ CP and digestible Lys levels from 14.2 to $17.2 \mathrm{~g} / \mathrm{kg}$ or diets with $184 \mathrm{~g} / \mathrm{kg} \mathrm{CP}$ with digestible Lys levels from 12.6 to $14.1 \mathrm{~g} / \mathrm{kg}$. This is an important factor that needs to be considered in dose-response assays to estimate Lys requirements, since birds consuming lower protein levels synthesize smaller amounts of protein and have lower Lys requirements (Pesti, 2009). In addition, amino acids are needed according to dietary protein level (Pesti, 2009), which determines feed consumption. In our study, the female poults fed higher protein levels maintained consumption levels and grow more; resulting in improved feed utilization efficiency in comparison to those obtained by Boling and Firman (1998) and Thompson et al. (2004).

The criteria used for response can also affect the estimated digestible Lys requirements and should be carefully considered to maximize the desired parameter of performance (Table 6). Generally, studies with broilers found that the digestible Lys requirement determined for optimum feed conversion was substantially higher than was determined for maximal ADG (Baker et al., 2002). In the initial phase of this study, as well as in the growth and finishing phases, a lower digestible Lys requirement was observed for optimum FE than for maximal ADG. These results are consistent with other studies with female turkeys in the initial phase (Boling and Firman, 1998; Thompson et al., 2004). In this case, ADG is maximized near the fourth experimental digestible Lys level, whereas the ADFI is almost constant near the third digestible Lys level. On the other hand, when the ADG and ADFI reach the maximal response, the ADG is almost constant, but ADFI decreases as the digestible Lys level increases in the growth and finishing periods. Baker et al. (2002), which stated that this effect occurred only with Lys, also made this observation and could not explain these results. A possible explanation was given by Ferguson and Gous (1997), which suggested that the animal increases its feed intake in an attempt to obtain more of the limiting nutrient to meet its requirement until a dietary concentration is reached where performance is so constrained that feed intake falls.

Previous studies have shown that increasing digestible Lys levels in turkey feeds had a positive impact on carcass weight (Veldkamp et al., 2003). In this study, increasing digestible Lys levels promoted a quadratic response for CY, which contradicts the results from Waldroup et al. (1998), who found that digestible Lys levels had no influence on carcass yield. Another observation in the current study is that the digestible Lys requirements for optimal CY were higher than for FE and ADG (Fig. 3), which was also observed in previous studies (Lehmann et al., 1996; Lemme et al., 2004). Carcass characteristics are important factors to consider in the evaluation of alternative AA feeding programs (Lemme et al., 2006). As body fat may account for the increase in BW of turkeys, meeting the digestible Lys requirements of the turkeys to improve carcass weight and carcass yield would be interesting after these birds achieve the market weight. On the other hand, the recommendations of digestible lysine levels in female turkey diets based on ADG could be used to increase growth rate and reduce the days required to reach market weight.

In conclusion, the optimal digestible Lys levels for better ADG and FE responses were $16.69 \mathrm{~g} / \mathrm{kg}$ and $16.55 \mathrm{~g} / \mathrm{kg}$ from 0 to $25 \mathrm{~d}, 14.25 \mathrm{~g} / \mathrm{kg}$ and $14.15 \mathrm{~g} / \mathrm{kg}$ from 26 to $48 \mathrm{~d}$, and $12.23 \mathrm{~g} / \mathrm{kg}$ and $12.07 \mathrm{~g} / \mathrm{kg}$ from 49 to $68 \mathrm{~d}$, respectively, and the digestible Lys for $\mathrm{CY}$ was $12.32 \mathrm{~g} / \mathrm{kg}$. These recommendations were similar to the recommendations presented in nutritional guidelines for the strain, except in the period from 0 to $25 \mathrm{~d}$. Therefore, it is highly recommended to validate these requirements in further investigations through performance trials to achieve a more reliable recommendation in the initial period. 


\section{Acknowledgements}

Authors gratefully acknowledge the support from the Brazilian Foods (BRF) Company in this study, and we declare that there is no conflict of interest in this study.

\section{References}

AOAC, 2005. Official Methods of Analysis, 16th ed. Assoc. Off. Anal. Chem., Arlington, VA.

Ajinomoto, 2015. Poultry Research Report 9 (accessed 27.10.5) http://www.lysine.com/pdf/poultry/prr9. pdf.

Appelt, M.D., 2010. Digestible Lysine in Diets for Female Turkeys MsC Diss. Paraná Federal Univ., Curitiba.

Aviagen Turkeys, 2013. Management Guidelines for Raising Commercial Turkeys (accessed 20.10.13)

https://www.aviagenturkeys.com/media/183481/aviagen_commercial_guide.pdf.

Baker, D.H., Batal, A.B., Parr, T.M., Augspurger, N.R., Parsons, C.M., 2002. Ideal ratio (relative to lysine) of tryptophan, threonine, isoleucine, and valine for chicks during the second and third weeks posthatch. Poult. Sci. 81, 485-494.

Boling, S.D., Firman, J.D., 1998. Digestible lysine requirement for female turkeys during the starter period. Poult. Sci. 77 (4), $547-551$.

Case, L.A., Miller, S.P., J.Wood, B., 2010. Factors affecting breast meat yield in turkeys. Worlds Poult. Sci. J. 66 (2), 189-202, http://dx.doi.org/10.1017/S0043933910000255.

Draper, N.R., Smith, H., 1981. Applied Regression Analysis, 2nd ed. John Wiley and Sons, New York, NY.

Ferguson, N.S., Gous, R.M., 1997. The influence of heat production on voluntary food intake in growing pigs given-protein deficient diets. Anim. Sci. 64 365-378, http://dx.doi.org/10.1017/S1357729800015939.

Firman, J.D., 1992. Amino acid digestibilities of soybean meal and meat meal in male and female turkeys of different ages. J. Appl. Poult. Res. 1, 350-354, http://dx.doi.org/10.1093/japr/1.3.350.

Lehmann, D., Pack, M., Jeroch, H., 1996. Responses of growing and finishing turkey toms to dietary lysine. Poult. Sci. 75 (6), $711-718$.

Lemme, A., Strobel, E., Hoehler, D., Matzke, W., Pack, M., Jeroch, H., 2002. Impact of graded levels of dietary lysine on performance in turkey toms 5-8 and 13-16 weeks of age. Arch. Geflügelk 66 (3), 102-107.

Lemme, A., Frackenpohl, U., Petri, A., Meyer, H., 2004. Effects of reduced dietary protein concentrations with amino acid supplementation on performance and carcass quality in turkey toms 14-140 days. Int. J. Poult. Sci. 3 (6), 391-399, http://dx.doi.org/10.3923/ijps.2004.391.399.

Lemme, A., Frackenpohl, U., Petri, A., Meyer, H., 2006. Response of male BUT Big 6 turkeys to varying amino acid feeding programs. Poult. Sci. 85 (4), 652-660, http://dx.doi.org/10.1093/ps/85.4.652.

NRC, 1994. Nutrient Requirements of Poultry, 9th rev. ed. Natl. Acad. Press, Washington, DC.

Pesti, G.M., Vedenov, D., Cason, J.A., Billard, L., 2009. A comparison of methods to estimate nutritional requirements from experimental data. Br. Poult. Sci. 50 (1), 16-32, http://dx.doi.org/10.1080/00071660802530639.

Pesti, G.M., 2009. Impact of dietary amino acid and crude protein levels in broiler feeds on biological performance. J. Appl. Poult. Res. 18 (3), 477-486 http://dx.doi.org/10.3382/japr.2008-00105.

Robbins, K.R., Norton, H.W., Baker, D.H., 1979. Estimation of nutrient requirements from growth data. J. Nutr. 109, 1710-1714.

Rostagno, H.S., Albino, L.F.T., Donzele, J.L., Gomes, P.C., Oliveira, R.F., Lopes, D.C., Ferreira, A.S., Barreto, S.L.T., Euclides, R.F., 2011. Brazilian Tables for Poultry and Swine: Composition of Feedstuffs and Nutritional Requirements, 3rd ed. UFV Publisher, Viçosa, MG.

Thompson, K.A., Blair, E., Baker, K.A., Firman, J.D., 2004. Digestible lysine requirement for hen turkeys from 0 to 6 weeks of age. Int. J. Poult. Sci. 3 (9), 558-562, http://dx.doi.org/10.3923/ijps.2004.558.562.

Thompson, K.A., Baker, K.A., Firman, J.D., 2005. Digestible lysine requirement for hen turkeys from 6 to 12 weeks of age. Int. J. Poult. Sci. 4 (9), 639-644, http://dx.doi.org/10.3923/ijps.2005.639.644.

TrindadeNeto, M.A., Kobashigawa, E., Namazu, L.B., Takeara, P., Araújo, L.F., Albuquerque, R., 2010. Digestible lysine and zinc chelate for male broilers from 22 to 42 days of age. R. Bras. Zootec. 39 (11), 2460-2470, http://dx.doi.org/10.1590/S1516-359820100020.

Veldkamp, T., Kwakkel, R.P., Ferket, P.R., kogut, J., Verstegen, M., 2003. Growth responses to dietary lysine at high and low ambient temperature in male turkeys. Poult. Sci. 82, 1733-1746.

Waldroup, P.W., England, J.A., Kidd, M.T., Kerr, B.J., 1998. Dietary arginine and lysine in large white toms. 1. Increasing arginine: lysine ratios does not improve performance when lysine levels are adequate. Poult. Sci. 77, 1364-1370. 